\title{
STOCK MARKET REACTIONS TO REGULATORY EVENTS ON EMISSION TRADING: EVIDENCE FROM THE EUROPEAN AIRLINE INDUSTRY
}

İsmail Çağrı ÖZCAN ${ }^{1}$

Received (Başvuru Tarihi): 08/04/2019

Accepted (Kabul Tarihi): 14/06/2019

Published Date (Yayın Tarihi): 26/06/2019

\begin{abstract}
The inclusion of international aviation emissions into the European Union Emission Trading Scheme starting from 2012 is expected to bring additional costs to flights having either origins or destinations at a European Union airport. In turn, this should bring new costs to airlines. The aim of this paper is to analyze how financial markets reacted to the official announcements on this regulatory change. Our findings, using an eventstudy methodology and employing a sample of 20 European airlines' stocks, reveal that the stock markets tend not to take these regulatory changes into account in the valuation of the European airlines' stocks. We also document that the magnitude of the reaction of low-cost airlines is not statistically significant than that of full-service network airlines' reaction.
\end{abstract}

Keywords: European Union Emission Trading Scheme, Stock Market Reactions, Event-Study Methodology, Airline Industry

Jel Codes: D53, G12, G14

\section{HISSE SENEDI PIYASALARININ EMISYON TICARETIYLE ILGILI DÜZENLEMELERE TEPKİII: AVRUPA HAVAYOLU ENDÜSTRISSINDEN BİR KANIT}

$\ddot{O} Z$

Uluslararası havacılığın 2012 yllından itibaren Avrupa Birliği (AB) Emisyon Ticareti Sistemine dâhil edilmesinin, başlangıç veya varış noktası bir AB havaalanı olan uçuşlara ilave bir maliyet getirmesi beklenmektedir. Bu da havayollarına yeni maliyetler getirecektir. Bu makalenin amact, finansal piyasaların bu düzenleyici değişikliğe yönelik duyurulara nasıl tepki verdiğini analiz etmektir. Olay analizi metodolojisi uygulanarak ve 20 adet Avrupal havayolu şirketine ait hisse senetleri kullanılarak elde edilen sonuçlar, hisse senedi piyasalarının havayolu şirketlerini değerlendirirken bu düzenlemeleri dikkate almama eğiliminde olduklarını göstermektedir. Çalışmanın diğer bir sonucuna göre, düsük maliyetli havayollarına ait hisse senetlerindeki tepkinin derecesi, tam hizmet sunan havayolu hisselerindeki tepkiden farklı değildir.

Anahtar Kelimeler: Avrupa Birliği Emisyon Ticareti Sistemi, Hisse Senedi Piyasası Tepkisi, Olay Analizi Metodolojisi, Havayolu Sektörü

JEL Kodları: D53, G12, G14

${ }^{1}$ Dr. Öğr. Üyesi, Ankara Yıldırım Beyazıt Üniversitesi, icozcan@ybu.edu.tr

https://orcid.org/0000-0002-3809-1847 


\section{INTRODUCTION}

186 countries have either signed or ratified Kyoto Protocol as of January 14, 2009, to stabilize greenhouse gas concentrations in the atmosphere. Because of the complexity of international civil aviation regulations, signing/ratifying nations preferred to exclude international civil aviation emissions from the Kyoto Protocol and delegated the issue to the International Civil Aviation Organization (ICAO). When European Union (EU) launched its European Union Greenhouse Gas Emission Trading System (EU ETS) in 2005 to reduce greenhouse gas emissions, it excluded international civil aviation emissions similar to what those nations did in Kyoto Protocol.

However, a couple of factors later forced the EU to rethink and revise its policy on international aviation emissions. First, efforts of ICAO failed to provide a concrete solution on the regulation of international aviation emissions since the very high number of bilateral aviation agreements among nations complicated and risked to reach an agreement covering all the ICAO member countries. Second, EU realized that despite the small share (3\%) of aviation activities in overall greenhouse gas emissions, the rapid growth of the airline industry would start threatening the greenhouse reductions achieved by other industries if no proactive action would be taken. For example, the forecasts of Macintosh and Wallace (2009) show that aviation CO2 emission would experience a more than 110\% increase between 2005 and 2025. Macintosh and Wallace (2009) also underline that actions to restrict demand would be necessary to stabilize aviation emissions. Third, the R\&D efforts to mitigate aviation-related greenhouse gas emissions are not promising drastic improvements. The pace of technological progress which will enable more fuel-efficient jet engines, aircraft designs and materials fails to catch up that of air traffic growth. Undoubtedly, when compared with past, the aviation industry enjoys the improved fuel efficiency of state-of-the-art jet engines, aerodynamic aircraft designs, and advanced material technology which helps use much lighter but durable materials. However, these technological improvements are not high enough to offset the aviation emission increases.

Another option, reducing the number of flights by employing larger aircraft instead of more frequent flights between origins and destinations, may help achieve only limited emission reductions. Givoni and Rietveld (2010) find that increased aircraft size with reduced frequency will help reduce the climate change impacts of aviation. Similarly, Morrel (2009) predicts that fuel efficiency gains of less than $1 \%$ can be achieved by using larger aircraft. However, employing larger aircraft with reduced frequency will reduce the service levels since passenger will have limited choice in the case of reduced frequencies of flights and therefore this option 
is unlikely to provide a major solution. Since such alternative solutions do not offer significant improvements, the EU decided to include international emissions to EU ETS.

On the other hand, being subjected to EU ETS will bring its own drawbacks directly for airlines and air passengers and indirectly for the overall economic activities. For airlines, being subjected to EU ETS means increased costs, reduced demand, and lower profits. From air passengers' point of view, the new regulatory structure will increase airfares. For the overall economic activities, the new system will create deadweight loss and GDP reductions stemming from the lowered economic activities in the airline industry and other industries directly or indirectly dependent on air transportation (like airport and tourism industries).

The scholars study numerous possible impacts of this new regulation on (i) airlines' competitiveness, (ii) air passenger demand to airline services, (iii) the aviation emissions, and (iv) overall economic activities. However, to the knowledge of the author, the stock market reactions of airlines to these regulatory changes remained untouched. This paper attempts to fill this gap by analyzing how stocks of European Airlines reacted to these regulatory changes. Based on a sample of 20 European airlines, our analyses suggest that, except for one trading day, stock markets tend to ignore these regulatory changes in the valuation of the European airlines. Section-2 of this paper summarizes the potential impacts of the inclusion of international aviation into EU ETS. Section-3 explains the methodology and data, and Section4 reports the findings of our analysis.

\section{POSSIBLE IMPACTS OF THE INCLUSION OF INTERNATIONAL AVIATION INTO EU ETS}

The inclusion of international aviation into EU ETS, by the Directive of European Parliament and of the Council (2008), will bring some adverse effects on the European airline industry $^{2}$. According to this directive, starting from January 1, 2012, flights from or to a Member State airport is subjected to EU ETS where the new system relies on the allocation of emission allowances to aircraft operators based on their historical emissions. The allowances for 2012 is equivalent to $97 \%$ of their historical emissions while this ratio decreases to $95 \%$ after 2013. If airlines emit more emission than they are freely allowed to, then they have to buy additional allowances through EU ETS. If they emit less, on the other hand, they can sell their allowances and earn some revenue. Through this scheme, the EU aims to encourage air carriers to employ more fuel-efficient aircraft and establish a system where the polluters pay for what

${ }^{2}$ Many non-European nations raised their opposition to the inclusion of aviation into EU ETS. Examples of the counter actions include prohibiting their airlines to participate in the new scheme and not to provide emissions data (Ibitz, 2015). 
they pollute. Given (i) the growing nature of the aviation industry, (ii) slow pace of technological progress on the fuel-efficient systems and designs, and (iii) reduced emissions allowances compared to historical values; most airlines apparently need to buy additional allowances for their emissions which mean additional costs for them. If airlines are able to pass on $100 \%$ of the emission-related costs to their passengers through increased airfares, then air passenger demand is expected to decrease. If they do not reflect any of the additional emissionrelated costs to their airfares, then their operating costs will increase, which in turn reduces their profitability. In between these two marginal cases, they can experience both a demand reduction and an increase in their operating costs at the same time.

Assuming an allocation method of grandfathering, Scheelhaase and Grimme (2007) find that the cost of buying additional allowances will range from $€ 0.01$ to $€ 2.97$ per passenger depending on the business model and scenario they use. They also predict that all four airlines in their sample will experience a demand reduction ranging from $0.01 \%$ to $2.44 \%$ if they shift the costs to their passengers equally. In a follow-up study, Scheelhaase et al. (2010) estimate that the EU ETS scheme will create moderate price increases in the range of $€ 10-€ 13$ for a typical long-haul flight assuming that the allowance price is $€ 20$. This price increase, in turn, will lead to a demand reduction of $2 \%$ according to their estimates. Employing a macro approach on this issue, Scheelhaase et al. (2012) predict that the inclusion of aviation into EU ETS will cost around $€ 20.5$ billion to the aviation industry over the 2012-2020 period assuming that the allowance price is $20 €$ per tonne of $\mathrm{CO} 2$.

In addition to bringing additional costs to the industry, the inclusion of international aviation may hurt competition. From the competition among EU airlines' point of view, allowances based on historical emissions may bring a competitive disadvantage for low-cost airlines against their full-service rivals since low-cost carriers are growing faster and their passengers are more price sensitive. Likewise, the inclusion of international aviation into EU ETS may also provide a competitive advantage for the non-EU airline over their EU competitors. First, non-EU airlines having direct flights between two non-EU airports may gain a cost advantage over an EU airline connecting the same airports but with a connection at an EU airport. For example, an Emirates flight from Dubai to New York is exempt from EU ETSrelated costs whereas a comparable Lufthansa flight having two legs and a stop within a German city (like Dubai-Frankfurt and Frankfurt-New York), or an Air France flight having two legs and a stop within a French city (like Dubai-Paris and Paris-New York) are subject to EU ETSrelated costs. Such a situation will arise concerns regarding competition between both airlines 
(Emirates Airlines versus Lufthansa and Emirates versus Air France) and airports (Dubai International Airport versus Frankfurt Airport or Dubai International Airport versus Paris Charles de Gaulle International Airport). Albers et al. (2009) attempt to analyze such issues. They calculate that, when compared to the direct flight of Continental Airlines between New York and Delhi, a two-leg flight of Lufthansa in the same route with a connection at Frankfurt will have an additional one-way cost of $€ 26.79$ per passenger. However, they conclude that this cost disadvantage is not high enough to force European airlines to instigate their network configurations. Similarly, Scheelhaase et.al. (2010) find that Continental Airlines will gain a competitive advantage over Lufthansa with the inclusion of international aviation emission into EU ETS. Their calculations reveal that being subjected to EU ETS has adverse effects on European network airlines.

The inclusion of international aviation into EU ETS will not only affect the airline industry but also both other industries (like tourism) relying on aviation and the whole European economy. Anger and Kohler (2010) predict that the decline rate in aviation emissions and EU GDP will be $3.8 \%$ (maximum) and $0.002 \%$, respectively. They claim the low carbon prices and the relative share of aviation emission within the overall emissions in the EU ETS are the underlying reasons for these insignificant changes. They recommend establishing a separate emission market for aviation to increase the effectiveness of aviation emission charges. In their paper, Mayor and Tol (2010) estimate the impact of the new EU ETS scheme on tourism markets. Their first finding is that the EU will lose some non-EU visitors to other tourism destinations. They also state that the EU tourists will have a tendency towards shorter and intraEU travels. Third, island EU countries depending on air transportation will lose EU tourist to other EU destinations. They calculate that the overall welfare loss of the world will be $€ 9.5$ billion, $€ 3.3$ billion of which will be of EU alone.

\section{METHODOLOGY AND DATA}

Our data set consists of 20 European airlines, which are listed in Table- $1^{3} .19$ airlines are from European Economic Area countries where the new legislation is effective. The last airline, Turkish Airlines, is from a candidate country for the European Union. Its flights will be subjected to new regulation once Turkey becomes a member state.

\footnotetext{
${ }^{3}$ The number of European airlines in our sample changes as new airlines were listed over time. The original number is 11 and this figure increases to 19 in 2008. We excluded one airline from the sample for 2008 since its stock was suspended temporarily.
} 
Table 1. List of European Airlines in the Sample

\begin{tabular}{|c|c|}
\hline Full Service Airlines & Low-Cost Airlines \\
\hline 1. $\mathrm{SAS}$ & 1. AIR BERLIN \\
\hline 2. FINNAIR & 2. EASYJET \\
\hline 3. LUFTHANSA & 3. SKYEUROPE \\
\hline 4. AIR FRANCE-KLM & 4. AER LINGUS \\
\hline 5. BRITISH AIRWAYS & 5. RYANAIR \\
\hline 6. IBERIA & 6. EUROFLY \\
\hline 7. AUSTRIAN AIRLINES & 7. VUELING \\
\hline 8. TURKISH AIRLINES & 8. NORWEGIAN AIR SHUTTLE \\
\hline 9. CYPRUS AIRWAYS & \\
\hline 10. AEGEAN AIR & \\
\hline 11. ICELAND AIR & \\
\hline 12. ALITALIA & \\
\hline
\end{tabular}

Efficient market hypothesis (EMH) states that the prices of traded assets, including but not limited to stocks, reflect the available information and react instantly to new information. In our case, assuming that EMH is valid, the prices of airline stocks should decline if financial markets believe that the new regulations will bring additional significant costs and/or demand reductions to the EU airlines.

In our analysis, we use the event-study methodology. Developed by Fama et. al. (1969) and Fama (1976), event-study methodology relies on the assumption that financial markets are efficient and they are able to evaluate the impact of new information on financial instruments. The event-study methodology is based on the idea that the new information should cause an abnormal return (either positive or negative) on the affected stocks where the normal return is predicted by using time-series analysis. To calculate the normal returns of the stocks, firstly the return of the stock with respect to the stock market is modeled as follows:

$$
\text { Rit }=\alpha i+\beta i R m t+\varepsilon i t
$$

where

$\alpha \mathrm{i}:$ constant

$\beta i$ : the daily return of the stock market (say London Stock Exchange)

Rit : the daily return of the stock (say British Airways) 
cit : error term

Model (1) is predicted for each airline stock before the event (which are the regulatory announcements in the case of this paper) over a number of days (usually between 120 to 210 days). Then the abnormal return for each airline stock is calculated after the event by the following equation:

$$
\text { ARit }=\text { Rit }-\hat{\alpha}-\hat{\beta} \text { mit }
$$

where

ARit : abnormal return (positive or negative) of the stock after the event

A group of studies focuses on the stock market reactions to new information for the airline industry. Some studies analyze the stock market responses to totally unexpected events like air crashes and terrorist attacks in which airlines are involved [(Bosch et. al., 1998), (Carter and Simkins, 2004), (Drakos, 2004)] whereas another body of literature examine the effects of airline mergers and acquisitions, which are less unpredicted compared to air crashes and terrorist attacks [(Knapp, 1990), (Singal, 1996), (Zhang and Aldridge, 1997), (Friesen, 2005), (Flouris and Swidler, 2004)]. But event-study methodology for regulatory changes may possess some problems. Unlike aircraft accidents, terrorist attacks, and mergers\&acquisitions (to some extent), regulatory changes are neither instant nor unexpected. In our case, many previous signals existed before the final enactment of Directive of the European Parliament and of the Council on November 19, 2008. One possible outcome of this anticipation is that the impact of the new regulation may already be priced-out by the financial markets. In other words, rather than a drastic price adjustment after the new information is made public, gradual price adjustment might occur over a period of time even before the analysis period and therefore make itself hard to be detected by event-study methodology. 
Table 2. The Timeline of Regulatory Announcements

\begin{tabular}{|c|c|c|c|}
\hline Event \# & Date & EU Body & Announcement \\
\hline 1 & December 1, 1999 & $\begin{array}{l}\text { Commission of the } \\
\text { European } \\
\text { Communities }\end{array}$ & $\begin{array}{l}\text { The communication which calls for voluntary and proactive } \\
\text { efforts (if necessary) to reduce environmental impacts of air } \\
\text { transportation and underlines to establish a charging system for } \\
\text { environmental costs. }\end{array}$ \\
\hline 2 & October 13, 2003 & $\begin{array}{l}\text { European Parliament } \\
\text { and of the Council }\end{array}$ & $\begin{array}{c}\text { The directive which directs EU commission to draw up a report } \\
\text { on how and whether of various relevant sectors should be } \\
\text { included in EU ETS. }\end{array}$ \\
\hline 3 & February 9, 2005 & $\begin{array}{l}\text { Commission of the } \\
\text { European } \\
\text { Communities }\end{array}$ & $\begin{array}{l}\text { The communication which argues that aviation should be included } \\
\text { in any post- } 2012 \text { climate change regime. }\end{array}$ \\
\hline 4 & September 27, 2005 & $\begin{array}{l}\text { Commission of the } \\
\text { European } \\
\text { Communities }\end{array}$ & $\begin{array}{l}\text { The communication which outlines the current regulation for } \\
\text { emissions and makes some reference to aviation emissions. }\end{array}$ \\
\hline 5 & December 2, 2005 & $\begin{array}{c}\text { Council of } \\
\text { Environment Ministers }\end{array}$ & $\begin{array}{l}\text { Press release following 2697. Council Meeting which underlines } \\
\text { the need to regulate aviation emissions }\end{array}$ \\
\hline 6 & December 20, 2006 & $\begin{array}{l}\text { Commission of the } \\
\text { European } \\
\text { Communities }\end{array}$ & $\begin{array}{l}\text { The proposal for the directive which includes aviation into the } \\
\text { European emission trading system }\end{array}$ \\
\hline 7 & November 19, 2008 & European Parliament & Approval of the directive \\
\hline
\end{tabular}

As the value of a firm is the present value of expected future net revenues, one might expect that introduction of EU ETS regulation will decrease airlines' values since the demand to airline services will decrease and emission costs will arise. Therefore, though a new regulation is relatively more predictable from the capital markets' point of view, we expect to see a decrease in the values of airlines' stocks after the announcements of EU policy changes. To test our hypothesis, we use events 3, 6, and 7 at Table-2. We do not include events 1, 2, 4, and 5 since events 1,2 were too primitive and intangible to analyze whereas events 4 and 5 were lacking the necessary estimation periods for the event-study methodology. For events 3, 6, 7, we first predict Estimation-1 and then we calculate the abnormal returns by using Estimation-2. To test for different time intervals, we calculated the abnormal returns for days $+1,+2,+3,+4,+5$ where day 0 is the date of the event of the official announcement on regulatory change. To test for aggregate abnormal returns, we also calculate cumulative abnormal returns for the periods $(1,3),(1,5),(1,10),(1,20)$ for all these three events. 
In the second part of our analyses, we test whether the stock reactions of low-cost airlines differ from those of full-service airlines. This question is important because it challenges the EU's argument that competition among airlines would not be affected by the introduction of the new scheme. To be able to make a comparison, we form two portfolios. The first portfolio consists of low-cost airlines and the second one consists of full-service airlines. Then for the last event, approval of the directive, we test whether such a difference exists.

The new scheme may affect low-cost airlines in two opposite ways. On the positive side, since low-cost carriers tend to operate newer and therefore more efficient aircraft to achieve low-cost operations, one can predict that they will emit fewer greenhouse emissions per flight. Accordingly, their per passenger emission costs will be lower assuming that they will maintain their superior fleet composition over full-service airlines. On the negative side, their passengers are more price sensitive and even a marginal increase in airfares due to emission trading costs may result in larger demand reduction when compared to their full-service competitors. In addition, as a rapidly growing airline business model, low-cost airlines' growth rates are higher than those of full-service network airlines. Therefore, emission allowances based on historical values will create a much severe limitation for low-cost airlines. Accordingly, their allowances may not be high enough, which force them to buy larger amounts of additional allowances when compared to full-service airlines.

The relevant literature provides contradicting evidence on how the new scheme might affect the different airline business models. Scheelhaase and Grimme (2007) find that Ryanair (a low-cost airline) is expected to experience a larger passenger demand reduction than Lufthansa (a full-service network airline) by the implementation of new emission scheme. Morrell (2007) compare the projected impacts of three possible ETS allocation methods on three UK airlines having each having a different airline model (British Airways for full-service airlines, EasyJet for low-cost airlines, and Britannia/Thomsonfly for charter airlines). His results reveal that, when the free allocation is based on historical past emissions, EasyJet (the fastest growing airline of the sample) will be the most affected airline among others. For 2006, EasyJet is estimated to have an excess CO2 cost of $\$ 62,062,000$ while the comparable costs are \$5,456,000 and \$9,251,000 for British Airways and Britannia/Thomsonfly, respectively. Lu (2009) estimates that Easyjet will experience a higher percentage of demand reduction than Air France-KLM and British Airways if environmental charges, which take both noise and emissions into account, are implemented since airfares are lower in Easyjet as a low-cost airline. 
If these are the case, then the magnitude of the negative reaction of the low-cost carriers should be larger than that of the full-service airlines.

On the other hand, as discussed above, low-cost airlines might benefit from the new scheme under certain circumstances. Scheelhaase and Grimme (2007) make a comparison between the possible impacts of the new scheme on European airlines having different business models. They estimate that, assuming an allocation method of grandfathering, the cost of buying additional allowances will range from $€ 0.01$ to $€ 2.97$ per passenger depending on the business model and scenario they use and all 4 airlines in their sample will experience a demand reduction ranging $0.01 \%$ to $2.44 \%$ if they shift the costs to their passengers equally. In the case of benchmarking method of allocation, however, Ryanair and Condor will benefit from the new scheme while Lufthansa and Air Dolomiti will still have to bear additional costs.

\section{EMPIRICAL RESULTS}

The results of our analyses are provided at Table-3, Table-4, Table-5, and Table-6. Table-3 presents the findings of the event-study methodology where the event is the communication of the EU Commission arguing that aviation should be included in any post2012 climate change regime (Event\#3). The results of the Wilk W test suggest that we cannot reject that our observations are normally distributed except those for DAY+5. The t-statistics shown in Table 3 reveal that the abnormal returns of the European airlines' stocks are not statistically significant. In other words, we can conclude that the stock markets did not evaluate the communication of the EU Commission as a significant factor regarding the valuation of the EU airlines.

Table 3. Daily and Cumulative Abnormal returns for Event-3 (2005) Using One-Sample t-test

\begin{tabular}{|c|c|c|c|c|c|c|c|}
\hline & Observation & Mean & $\mathbf{t}$ & Std. Err. & Std. Dev. & $\begin{array}{c}\text { Prob>z for Shapiro- } \\
\text { Wilk W test for } \\
\text { normal data }\end{array}$ & [90\% Conf. Interval] \\
\hline$\overline{\mathrm{DAY}+1}$ & 11 & -.2748715 & -0.476 & .5779104 & 1.916712 & 0.105 & $-1.322312 \quad .7725686$ \\
\hline $\mathrm{DAY}+2$ & 11 & -.2758315 & -0.577 & .4780392 & 1.585477 & 0.435 & $-1.142259 \quad .590596$ \\
\hline$\overline{D A Y}+3$ & 11 & .2377217 & 1.1599 & .2049508 & .6797449 & 0.503 & $\begin{array}{ll}-.1337436 & .6091871\end{array}$ \\
\hline $\mathrm{DAY}+4$ & 11 & -.0954467 & -0.290 & .3293064 & 1.092186 & 0.603 & $\begin{array}{ll}-.6923018 & .5014083\end{array}$ \\
\hline $\mathrm{DAY}+5$ & 11 & .1589734 & 0.277 & .5748501 & 1.906562 & 0.081 & -.882921 .200867 \\
\hline DAY $(1,3)$ & 11 & -.3129813 & -0.575 & .5443505 & 1.805406 & 0.802 & $-1.299595 \quad .6736329$ \\
\hline DAY $(1,5)$ & 11 & -.2494546 & -0.278 & .8962648 & 2.972574 & 0.243 & $\begin{array}{ll}-1.8739 & 1.37499\end{array}$ \\
\hline
\end{tabular}

With respect to Event\#6, the introduction of the proposal for the directive which includes aviation into European emission trading system, our findings presented at Table 4 suggest that the stock markets again did not respond to the this proposed directive. None of the 
abnormal returns, which are reported in the third column of Table 4, are statistically significant meaning that these abnormal returns are not different than zero. We should note that our observations for DAY+1, DAY+2, DAY+4, and DAY+5 fail to meet the normality requirement according to Wilk W test.

Table 4. Daily and Cumulative Abnormal returns for Event-6 (2006) Using One-Sample t-test

\begin{tabular}{|c|c|c|c|c|c|c|c|}
\hline & Observation & Mean & $\mathbf{t}$ & Std. Err. & Std. Dev. & $\begin{array}{c}\text { Prob>z for Shapiro- } \\
\text { Wilk W test for normal } \\
\text { data }\end{array}$ & [90\% Conf. Interval] \\
\hline $\mathrm{DAY}+1$ & 14 & .1701232 & 0.412 & .4132239 & .1 .546142 & 0.003 & $-.5616687 \quad .9019152$ \\
\hline $\mathrm{DAY}+2$ & 14 & -.2730024 & -0.693 & .3939606 & 1.474066 & 0.051 & $-.9706804 \quad .4246756$ \\
\hline DAY +3 & 14 & .0081701 & 0.155 & .0527528 & .1973829 & 0.550 & $-.0852516 \quad .1015917$ \\
\hline DAY +4 & 14 & .1071137 & 1.3524 & .0791413 & .2961196 & 0.009 & $\begin{array}{ll}.0330402 & .2472677\end{array}$ \\
\hline $\mathrm{DAY}+5$ & 14 & .4682808 & 1.253 & .3736194 & 1.397956 & 0.059 & $-.1933742 \quad 1.129936$ \\
\hline DAY $(1,3)$ & 14 & -.0947091 & -0.280 & .3388666 & 1.267923 & 0.104 & $-.6948193 \quad .5054011$ \\
\hline DAY $(1,5)$ & 14 & .4806854 & 0.811 & .5928569 & 2.218267 & 0.729 & $-.5692247 \quad 1.530596$ \\
\hline
\end{tabular}

The last event we test is the approval of the directive in 2008 (Event\#7). We should underline that our observations meet the normality requirement according to Wilk $\mathrm{W}$ test. The results of the one-sample t-test suggest that the abnormal return of our sample consisting of 19 European airlines in the third day following the approval of the directive is different than zero. More concretely, we document that the value of the sample European airlines' stock experienced an abnormal decrease of $2.83 \%$ in the third following trading day (Table 5). In other trading days and in the cumulative abnormal returns, however, our findings do not depict a statistically significant change in the value of the stocks examined.

Table 5. Daily and Cumulative Abnormal returns for Event-7 (2008) Using One-Sample t-test

\begin{tabular}{|l|c|c|c|c|c|c|c|}
\hline & Observation & Mean & $\mathbf{t}$ & Std. Err. & Std. Dev. & $\begin{array}{c}\text { Prob>z for Shapiro-Wilk } \\
\text { W test for normal data }\end{array}$ & $\begin{array}{c}\text { [90\% Conf. } \\
\text { Interval] }\end{array}$ \\
\hline DAY +1 & 19 & .436633 & 0.478 & .9136126 & 3.982345 & 0.558 & -1.1476292 .020895 \\
\hline DAY +2 & 19 & 1.442514 & 0.980 & 1.471638 & 6.41472 & 0.761 & -1.1093993 .994428 \\
\hline DAY +3 & $\mathbf{1 9}$ & $\mathbf{- 2 . 8 3 1}$ & $\mathbf{- 3 . 1 0 1}$ & $\mathbf{0 . 9 1 3}$ & $\mathbf{3 . 9 7 9}$ & $\mathbf{0 . 8 9 0}$ & $\mathbf{- 4 . 4 1 3 5 2 9} \mathbf{1 . 2 4 7 9 0 9}$ \\
\hline DAY +4 & 19 & -1.059 & -1.034 & 1.024 & 4.464 & 0.190 & -2.8349557164196 \\
\hline DAY +5 & 19 & 1.004 & 1.635 & 0.614 & 2.676 & 0.252 & -.06098272 .068128 \\
\hline DAY (1,3) & 19 & -0.952 & -0.647 & 1.471 & 6.411 & 0.366 & -3.5018261 .598683 \\
\hline DAY (1,5) & 19 & -1.007 & -0.535 & 1.882 & 8.202 & 0.698 & -4.2701132 .255579 \\
\hline
\end{tabular}

As the last part of our analyses, we compare the abnormal returns of our two portfolios. The former portfolio consists of the stocks of the full-service airlines whereas the latter one includes those of the low-cost airlines. The aim of this comparison is to examine whether the 
stock markets have appreciated the relevant regulatory changes differently for these two distinct airline business models. In parallel to statistics reported in Table 5, the results shown in Table 6 reveal that the values of the stocks decreased in the third trading day after the event and this finding is statistically significant. Both the samples of full-service and low-cost airlines experienced an abnormal decrease in their market values. But the difference is not statistically significant. We can interpret this finding as investors believed that both types of airline business models would be affected equally due to the new regulatory scheme.

Table 6. Daily and Cumulative Abnormal returns for Event-7 (2008) Using One-Sample t-test

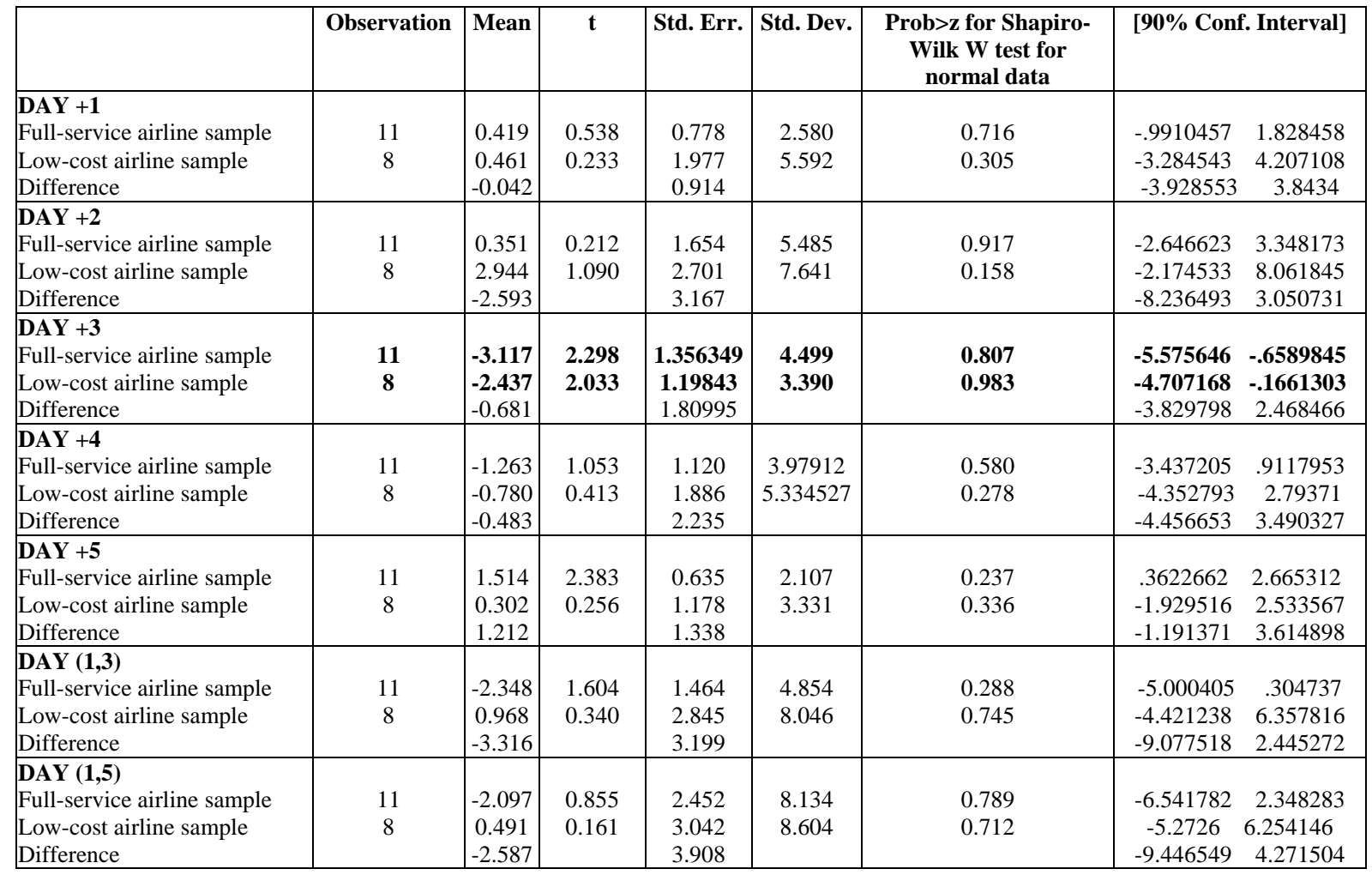

\section{CONCLUSION}

The inclusion of aviation into the EU emission trading scheme is expected to bring new costs on the airlines. The relevant literature largely focuses on the economic and financial burden of this new regulatory change on the airlines and airline related industries like tourism. However, the reaction of the stock markets to this new regulation remained relatively untouched. The aim of this study is to fill this gap by examining how the stock markets evaluated the regulatory announcements regarding the inclusion of aviation emissions into EU ETS. The reactions of the stock markets are important as, assuming the efficient market hypothesis is valid, new announcements should be truly incorporated into the stock prices. In 
other words, if the new announcement is expected to create an increase (decrease) in the firm's profitability, then the stock prices should increase (decrease).

Our results, based on the examination of three different events, suggest that financial markets tend not to take these regulatory changes into account in the valuation of the European airlines' stocks. Except for one trading day, we cannot get statistically significant abnormal returns. We can bring three explanations for this finding. First, as outlined in the above paragraph, the stock markets might believe that these regulatory changes would not create a significant financial burden on the European airlines' profitability. The relevant literature, such as Scheelhaase and Grimme (2007) suggesting a per passenger additional cost of $€ 0.01-€ 2.97$ and a demand reduction of $0.01 \%-2.44 \%$, provide supporting findings regarding this explanation. Second, the low number of observations in our samples can be a barrier to detect a statistically significant impact. Lastly, as we noted earlier, it is possible that the impacts of these regulatory announcements could be already priced out over a longer period of time rather than a drastic price change.

A follow-up study can compare the stock market reactions of the non-EU airlines with those of EU airlines to test how the financial markets appreciate the competition impact of the new emission regulations. 


\section{REFERENCES}

Albers, S., Buhne, J.A., \& Peters, H. (2009). Will the EU-ETS instigate airline network reconfigurations? Journal of Air Transport Management, 15(1), 1-6.

Anger, A., \& Kohler, J. (2010). Including aviation emissions in the EU ETS: Much ado about nothing? Transport Policy, 17, 38-46.

Bosch, J.C., Eckard, E.W., \& Singal, V. (1998). The Competitive Impact of Air Crashes: Stock Market Evidence. Journal of Law and Economics, 41, 503-519.

Carter, D.A., \& Simkins, B.J. (2004). The market's reaction to unexpected, catastrophic events: the case of airline stock returns and the September 11th attacks. The Quarterly Review of Economics and Finance, 44, 539558.

Commission of the European Communities. (2005). Reducing the Climate Change Impact of Aviation, COM (2005) 459 final, Brussels.

Commission of the European Communities. (2006). Proposal for a Directive of the European Parliament and of the Council amending Directive 2003/87/EC so as to include aviation activities in the scheme for greenhouse gas emission allowance trading within the Community, COM (2006) 818 final, Brussels.

Drakos, K. (2004). Terrorism-induced structural shifts in financial risk: airline stocks in the aftermath of the September 11th terror attacks. European Journal of Political Economy, 20, 435-446.

Fama, E.F. (1976). Foundations of Finance, New York, Basic Books.

Fama, E.F., Fisher, L., Jensen, M.C., \& Roll, R. (1969). The adjustment of stock prices to new information. International Economic Review, 10, 1-21.

Flouris, T., \& Swidler, S. (2004). American airlines' takeover of TWA: an ex-post analysis of financial market information. Journal of Air Transport Management, 10, 173-180.

Friesen, M. (2005). Capital Market's Assessment of European Airline Mergers and Acquisitions-The Case of Air France and KLM. 5th Swiss Transport Research Conference.

Givoni, M., \& Rietveld, P. (2010). The environmental implications of airlines' choice of aircraft size. Journal of Air Transport Management, 16(3), 159-167.

Ibitz, A. (2015). Towards a global scheme for carbon emissions reduction in aviation: China's role in blocking the extension of the European Union's Emissions Trading Scheme. Asia Europe Journal, 13(2), 113-130.

Knapp, W. (1990). Event Analysis of Air Carrier Mergers and Acquisitions. The Review of Economics and Statistics, 72, 703-707.

Lu, C. (2009). The implications of environmental costs on air passenger demand for different airline business models. Journal of Air Transport Management, 15, 158-165.

Macintosh, A., \& Wallace, L. (2009). International aviation emissions to 2025: Can emissions be stabilised without restricting demand? Energy Policy, 37, 264-273.

Mayor, K., \& Tol, R.S.J. (2010). The impact of European climate change regulations on international tourist markets. Transportation Research Part D, 15, 26-36.

Morrel, P. (2007). An evaluation of possible EU air transport emissions trading scheme allocation methods. Energy Policy, 35, 5562-5570. 
Morrel, P. (2009). The potential for European aviation $\mathrm{CO}_{2}$ emissions reduction through the use of larger jet aircraft. Journal of Air Transport Management, 15, 151-157.

Scheelhaase, J. D., \& Grimme, W. G. (2007). Emissions trading for international aviation-an estimation of the economic impact on selected European airlines. Journal of Air Transport Management, 13(5), 253-263.

Scheelhaase, J., Grimme, W., \& Schaefer, M. (2010). The inclusion of aviation into the EU emission trading scheme-Impacts on competition between European and non-European network airlines. Transportation Research Part D: Transport and Environment, 15(1), 14-25.

Scheelhaase, J., Schaefer, M., Grimme, W., \& Maertens, S. (2012). Cost impacts of the inclusion of air transport into the European emissions trading scheme in the time period 2012-2020. European Journal of Transport and Infrastructure Research, 12(4), 332-348.

Singal, V. (1996). Airline Mergers and Competition: An Integration of Stock and Product Price Effects. The Journal of Business, 69, 233-268.

Zhang, A., \& Aldridge, D. (1997). Effects of Merger and Foreign Alliance: An Event Study of the Canadian Airline Industry. Transportation Research Part E: Logistics and Transportation Review, 33, 29-42. 